\title{
Pemanfaatan Pos Pelayanan Terpadu di Perumahan Pondok Cilegon Indah
}

\author{
Fenny Raharyanti* Ahmad Jubaedi** Feriyanto***
}

\begin{abstract}
Abstrak
Pos Pelayanan Terpadu (Posyandu) yang pada periode pemerintahan orde baru populer dan berkontribusi besar pada kesehatan ibu dan anak, kini meredup dan mengalami penurunan peran. Ketika kasus-kasus bayi kurang gizi bermunculan, banyak pihak yang menyadari bahwa posyandu merupakan faktor yang berkontribusi pada perbaikan gizi balita. Tujuan penelitian ini adalah mengetahui keberadaan posyandu, pengetahuan dan kesadaran ibu balita, membawa balita ke posyandu, keaktifan kader menghidupkan posyandu, dan kelayakan fasilitas pendukung Posyandu di komplek Perumahan Pondok Cilegon Indah dengan karakteristik sosial-ekonomi penduduk yang beragam. Penelitian yang dilaksanakan pada bulan Desember 2006 mengamati populasi ibu balita dan kader bermukim di PCI dan mengikuti kegiatan posyandu yang telah dijadwalkan pada bulan Desember 2006. Ditemukan bahwa keberadaan Posyandu di Pondok Cilegon Indah masih dipertahankan hingga kini.Tingkat kemampuan ibu menerima penjelasan posyandu cukup baik, tetapi kesadaran ibu membawa balita ke posyandu rendah. Keaktifan kader menghidupkan kegiatan posyandu cukup baik dan kelayakan fasilitas pendukung program posyandu masih terbatas pada pelayanan posyandu minimal.
\end{abstract}

Kata kunci : Posyandu, komplek perumahan, kualitas kesehatan.

\section{Abstract}

Posyandu is a community-based health care program to improve the quality of life in Indonesia. This research is conducted to study the roles of posyandu in a community unit by observing the awareness of mothers and their satisfaction on the program activities and the quality of services provided. The community unit observed in this research is the one in Pondok Cilegon Indah Housing Complex (PCl) which consists of people with various income levels. This research is a descriptive study with a survey design which was conducted in December 2006 at PCl. The population is mothers living in the housing complex who are involved in the posyandu program activities. Samples are taken from two posyandu groups. Results show that posyandu programs in PCl have been beneficial since its inception in 1990. However, the number of mothers actively involved in the programs is of small portion compared with the total number of residents in the housing complex. Satisfaction on the programs is incredibly high, even though the services provided are quite limited to children weight monitoring, health food provision, vitamin A distribution, and children immunization.

Key words : Posyandu, housing complex, health quality.

*Program Studi Kesehatan Masyarakat STIKES Faletehan Serang, Banten Jl. Raya Cilegon Km.06 Pelamunan Kramatwatu Serang, Banten (e-mail: fennyraharyanti@yahoo.com) **Program Studi Kesehatan Masyarakat STIKES Faletehan Serang, Banten Jl. Raya Cilegon Km.06 Pelamunan Kramatwatu Serang, Banten (e-mail: ahmadjoe@gmail.com)

***Program Studi Kesehatan Masyarakat STIKES Faletehan Serang, Banten Jl. Raya Cilegon Km.06 Pelamunan Kramatwatu Serang, Banten (e-mail: ferry_stikesfa@yahoo.com) 
Posyandu adalah suatu forum komunikasi dan pelayanan kesehatan bagi masyarakat yang dilaksanakan oleh dan untuk masyarakat yang bernilai strategis mengembangkan sumber daya manusia sejak usia dini. Sebagai pusat kegiatan masyarakat, posyandu merupakan forum swadaya masyarakat yang memberikan pelayanan kesehatan sederhana dan keluarga berencana. ${ }^{1}$ Sasaran utama posyandu adalah bayi berusia kurang dari satu tahun, balita, ibu hamil, ibu menyusui dan ibu nifas serta wanita usia subur. Pada era orde baru, posyandu tumbuh dan berkembang subur serta berkontribusi besar pada perbaikan derajat kesehatan masyarakat. Kini, popularitas dan siar balita gizi buruk di berbagai provinsi di Indonesia.

Kegiatan posyandu dikemas dalam paket dua macam paket kegiatan yang disebut Panca Krida dan Sapta Krida. Kegiatan Panca Krida meliputi kesehatan ibu dan anak, keluarga berencana, imunisasi, peningkatan gizi dan penanggulangan diare. Sedangkan, Sapta Krida meliputi kegiatan kesehatan ibu dan anak, keluarga berencana, imunisasi, peningkatan gizi, penanggulangan diare, sanitasi dasar dan penyediaan obat esensial. 2,3 Persyaratan pendirian posyandu antara lain adalah berada di wilayah yang dihuni oleh minimal 100 orang balita dan 120 kepala keluarga. Persyaratan lainnya adalah disesuaikan dengan kemampuan bidan desa dan jarak antara kelompok rumah, jumlah kepala keluarga dalam satu tempat. ${ }^{4}$

Pondok Cilegon adalah komplek perumahan yang terdiri dari berbagai tipe bangunan dan variasi status ekonomi sosial penghuni yang berpotensi besar mengembangkan fasilitas kesehatan. Hal tersebut antara lain terlihat pada banyak keluarga baru yang masih mempunyai anak balita. Hingga kini, eksistensi posyandu masih dipertahankan di seluruh klaster perumahan sehingga patut menjadi panutan bagi lingkungan perumahan yang lain. Pemanfaatan posyandu yang belum terlihat optimal dapat disebabkan oleh ketidaktahuan dan keengganan orang tua untuk membawa anaknya ke posyandu atau pilihan keluarga untuk mendapat pelayanan kesehatan dan keluarga berencana di tempat lain seperti klinik atau rumah sakit.

Tujuan penelitian untuk mengetahui keberadaan posyandu, pengetahuan dan kesadaran para ibu untuk membawa balita ke posyandu, keaktifan kader menghidupkan kegiatan posyandu dan kelayakan fasilitas pendukung program posyandu di Kompleks Perumahan Pondok Cilegon Indah.

\section{Metode}

Penelitian yang dilaksanakan pada bulan Desember 2006 ini menggunakan metode penelitian kualitatif metode pengumpulan data survei dan studi kualitatif wawancara mendalam. Sampel diambil secara purposive sampling, yaitu pengambilan pada dua titik kegiatan posyandu. Subjek penelitian meliputi $25 \mathrm{ibu}$ dan balitanya yang meliputi 15 orang berasal dari Posyandu Perumahan Blok B (Kelompok I) dan 10 orang pengunjung Posyandu Perumahan Blok C (Kelompok II) yang dilaksanakan pada tanggal 19 dan 22 Desember 2006. Instrumen penelitian meliputi kuesioner untuk para ibu balita dan daftar pertanyaan untuk wawancara mendalam bagi para kader. $^{5}$

\section{Hasil \\ Karakteristik Responden}

Usia ibu balita pengunjung posyandu berkisar 22 42 tahun dengan usia rata-rata balita 21 bulan yang termuda 4 bulan dan yang tertua 54 bulan dan berat badan berkisar 7,8-17,0 kg. Hanya ada 2 kategori pekerjaan ibu balita yaitu ibu rumah tangga $(92,0 \%)$ dan karyawati swasta 2 orang $(8,0 \%)$. Sebagian besar (56\%) warga berstatus soaial ekonomi menengah dengan berpenghasilan Rp1-3 juta per bulan. Pendidikan ibu sebagian besar $(72 \%)$ sekolah menengah atas, sementara yang tidak bersekolah dan yang berpendidikan sekolah dasar masing-masing hanya 1 orang. Sekitar 20\% ibu balita tersebut berpendidikan perguruan tinggi (Lihat Tabel 1).

\section{Pengetahuan Posyandu}

Ibu yang secara rutin membawa balita mereka ke posyandu sesuai jadwal relatif kecil (20\%). Mereka yang tidak membawa balita ke posyandu dengan alasan lupa dan sudah dibawa ke tenaga kesehatan. Para ibu balita tersebut yang menyatakan mendapat pelayanan baik cukup tinggi, meliputi penimbangan berat badan (96\%), imunisasi $(76,0 \%)$, pemberian makanan bergizi $(52 \%)$, pemberian vitamin A $(80 \%)$ (Lihat Tabel 2).

Semua responden menyatakan bahwa pelayanan para kader di kedua posyandu ternyata memuaskan dan sebagian besar responden (84\%) merasa bahwa fasilitas yang disediakan oleh posyandu adalah layak.

\section{Wawancara Mendalam}

Kedua kelompok ibu balita tersebut sama-sama mengetahui proses awal pendirian posyandu, kriteria dan metoda perekrutan kader. Posyandu berdiri sejak 1990, kader dipilih secara sukarela dengan persyaratan utama bersedia bekerja sukarela untuk posyandu. Pengelola posyandu kelompok I terdiri dari seorang ketua yang dibantu 4 orang kader sedangkan posyandu kelompok II terdiri atas seorang ketua yang dibantu 6 orang kader. Kedua posyandu sering melakukan pelatihan, kelompok I mengikuti program Dinas Kesehatan Kota Cilegon dan kelompok II merupakan wilayah kerja Puskesmas Kramatwatu Serang. Pelatihan kader bertu- 
Tabel 1. Distribusi Frekuensi Penghasilan Keluarga

\begin{tabular}{lcl}
\hline Penghasilan Keluarga & Frekuensi & $\%$ \\
\hline Kurang dari Rp. 1 juta/bulan & 2 & 8,0 \\
Antara Rp.1-3 juta/bulan & 14 & 56,0 \\
Lebih dari Rp. 3 juta/bulan & 5 & 20,0 \\
Penghasilan tidak tetap & 4 & 16,0 \\
\hline Total & $\mathbf{2 5}$ & $\mathbf{1 0 0 , 0}$ \\
\hline
\end{tabular}

Tabel 2. Distribusi Frekuensi Layanan Posyandu

\begin{tabular}{ll}
\hline Jenis Layanan & $\%$ \\
\hline Penimbangan berat badan & 96,0 \\
Imunisasi & 76,0 \\
Pemberian makanan bergizi & 52,0 \\
Pemberian vitamin A & 80,0
\end{tabular}

juan meningkatkan pengetahuan, ketrampilan dan percaya diri untuk melaksanakan tugas kader melayani masyarakat di posyandu dan di rumah pada saat kunjungan rumah.

Menurut kelompok I, pada awal tahun 90-an pengunjung posyandu tinggi sampai mencapai lebih dari 100 orang. Hal tersebut kemungkinan disebabkan oleh jumlah bidan masih sedikit, sehingga akses bidan rendah dan ibu balita banyak yang memilih pelayanan di posyandu. Kini, peserta yang datang ke posyandu terlihat menurun banyak, tidak lebih dari 20 atau rata-rata 15 orang setiap kegiatan. Namun, pada saat pemberian vitamin A, kunjungan dapat meningkat sampai lebih dari 100 orang. Menurut kelompok II, belum semua ibu membawa balita ke posyandu setiap bulan. Untuk mencapai target kehadiran ibu hamil ke posyandu dilakukan berbagai upaya antara lain : penataan kerapian dan kebersihan posyandu, meningkatkan pemberian informasi dengan mendatangi rumah dan pengumuman lewat masjid, kader mengizinkan ibu dan anak balita memeriksa ke posyandu meski tidak membawa Kartu Menuju Sehat (KMS), memberi hadiah bagi ibu yang secara rutin membawa balitanya sejak usia 0-60 bulan, dan kader dan petugas puskesmas menyarankan masyarakat membawa balita ke posyandu. Upaya kelompok II mengajak para ibu membawa balita ke posyandu meliputi : mendatangi rumah penduduk, mengajak melalui telepon, mengumumkan melalui mesjid terdekat.

Kelompok I tidak pernah menghentikan kegiatan sejak posyandu didirikan sampai sekarang. Sementara, posyandu kelompok II pernah mengalami putus kegiatan, tetapi waktunya tidak tercatat. Putus kegiatan posyandu umumnya disebabkan oleh pengurus/kader pindah rumah. Posyandu kelompok I tergolong Posyandu Pratama Madya, meski sebagian besar pembiayaan di- subsidi oleh warga. Sedangkan, kelompok II termasuk posyandu mandiri dengan pembiayaan oleh warga secara mandiri.

\section{Pembahasan}

Jumlah seluruh penduduk di dua wilayah komplek perumahan tampaknya tidak berhubungan dengan jumlah kunjungan posyandu. Hal tersebut disebabkan oleh tidak semua ibu membawa balitanya ke posyandu pada saat kegiatan berlangsung. Hal tersebut terlihat pada cakupan kunjungan yang rendah $(<50 \%)$. Ibu balita yang disertakan dalam penelitian ini umumnya dengan usia perkawinan yang relatif muda, sehingga baru mempunyai satu anak balita. Sebagian besar ibu balita tersebut $(92 \%)$ adalah ibu rumah tangga yang tidak kerja, sehingga dapat mengunjungi posyandu secara rutin.

Sebagian besar ibu balita yang diamati tersebut berpendidikan sekolah menengah atas $(72,0 \%)$ dan perguruan tinggi $(20,0 \%)$. Hal tersebut mungkin mendukung penyerapan berbagai pengetahuan, khususnya tentang tumbuh kembang anak yang selanjutnya berdampak pada kesediaan membawa anak balita secara rutin ke posyandu. Beberapa ibu lupa membawa balita ke posyandu, antara lain disebabkan oleh : tidak mencatat atau tidak menjadwalkan kegiatan tersebut. Ada keperluan mendadak yang tidak dapat ditinggalkan. Perhatian yang kurang terhadap posyandu. Alasan lain yang ditemukan antara lain adalah balita trauma/takut ditimbang dan kepercayaan pada dokter atau bidan, karena langsung dapat mendiagnosis perkembangan kesehatan balita serta saran atau pengobatan yang lebih tepat. Para orang tua tidak mempermasalahkan biaya pemeriksaan oleh tenaga kesehatan profesional. Terutama jika orang tua mempunyai jaminan asuransi kesehatan dari tempat mereka bekerja. ${ }^{6}$

Jenis pelayanan posyandu yang diberikan di kedua tempat lokasi tersebut masih merupakan pelayanan minimal. Berdasarkan Pedoman Umum Revitalisasi Posyandu 2001, jenis pelayanan minimal yang perlu diberikan kepada balita dan baduta meliputi: Penimbangan untuk memantau pertumbuhan dengan perhatian harus pada anak yang selama tiga kali penimbangan mengalami pertumbuhan yang lebih rendah dari 200 gram/bulan serta anak dengan tingkat pertumbuhan di bawah garis merah KMS. Makanan pendamping ASI dan vitamin A diberikan dua kali setahun. Pemberian PMT pada anak dengan pertumbuhan yang kurang dari 200 gram/bulan serta anak dengan berat badan dibawah garis merah KMS. Memberikan imunisasi dan memantau tanda-tanda lumpuh layuh. Memantau kejadian ISPA dan diare dan jika diperlukan melakukan rujukan.

Posyandu yang dekat dengan pemukiman tersebut 
sangat membantu para ibu dan balita mengunjungi posyandu terdekat pada setiap jadwal kegitan yang telah ditentukan. Lokasi kedua posyandu memenuhi persyaratan lokasi posyandu tempat yang mudah dikunjungi oleh masyarakat. Pelayanan para kader memuaskan para ibu balita yang telah dikenal baik, karena mereka secara rutin dan sering berkunjung ke posyandu secara suka rela serta senantiasa membangun suasana persaudaraan yang kondusif. Sebagian besar ibu balita (84\%) menyatakan fasilitas posyandu telah layak. Hal tersebut mengindikasikan bahwa posyandu telah memberikan fasilitas terbaik untuk para balita. Hanya sebagian kecil responden yang merasakan fasilitas posyandu belum layak karena mendapatkan fasilitas yang jauh lebih lengkap di fasilitas pelayanan kesehatan profesional.

Agar posyandu tidak bersifat monoton, pelayanan tersebut dapat dikembangkan antara lain mencakup ${ }^{7}$ : a) Program Pengembangan Anak Dini Usia (PADU) yang diintegrasikan dengan Program Bina Keluarga Balita (BKB) dan kelompok bermain yang lain. b) Penyediaan air bersih dan penyehatan lingkungan pemukiman (PABPLB). c) Program Diversifikasi Pertanian Tanaman Pangan. d) Program sarana air minum dan jamban keluarga (SAMIJAGA) dan perbaikan lingkungan pemukiman. e) Pemanfaatan pekarangan. f) Kegiatan lain seperti : TPA, pengajian, taman bermain, arisan, peragaan teknologi tepat guna dan sejenisnya.

\section{Wawancara Mendalam}

Ada beberapa temuan yang sama dan berbeda hasil wawancara mendalam pada kelompok I dan kelompok II. Untuk pertanyaan 1-3 tentang awal pendirian, cara rekrutmen kader dan kriteria kader posyandu, kedua kelompok memberikan jawaban yang sama. Posyandu didirikan sejak tahun 1990 dan rekrutmen dilakukan tanpa persyaratan tertentu kecuali bersedia bekerja secara sukarela. Organisasi kader posyandu kelompok I meliputi seorang ketua yang mengkoordinasikan 4 orang kader. Secara ideal, kader berjumlah lima orang dengan tugas masing-masing adalah pendaftaran, penimbangan, pencatatan, penyuluhan dan pelayanan. Kader yang terlalu banyak tidak akan berfungsi dengan baik. Pada kelompok II, posyandu dipimpin seorang ketua yang mengkoordinasikan 6 orang kader yang tidak mendapat honorarium. Setiap kader telah bertugas dengan baik. Rekrutmen kader posyandu masih diperlukan mengingat kemungkinan kader pindah alamat atau lanjut usia. ${ }^{8}$

Pelatihan seringkali dilakukan oleh kedua kelompok tersebut. Pelatihan kader bertujuan untuk meningkatkan pengetahuan dan keterampilan sekaligus dedikasi kader agar timbul kepercayaan diri untuk dapat melaksanakan tugas sebagai kader dalam melayani masyarakat, baik di posyandu maupun saat melakukan kunjungan rumah. Materi dalam pelatihan kader dititikberatkan pada keterampilan teknis menyusun rencana kerja kegiatan di posyandu, cara menghitung kelompok sasaran yang menjadi tanggung jawab posyandu, cara menimbang, menilai pertumbuhan anak, cara menyiapkan kegiatan pelayanan sesuai kebutuhan anak dan ibu, menyiapkan peragaan cara pemberian makanan pendamping ASI dan PMT untuk anak yang pertumbuhannya tidak sesuai umur dan anak dengan berat badan tidak naik, serta memantau perkembangan ibu hamil dan ibu menyusui dan sebagainya. Agar pelatihan kader dapat berjalan efektif, maka diperlukan unsur pelatih kader yang mampu dan berdedikasi dalam memberikan materi pelatihan secara efektif dan berkesinambungan, yakni melalui pendampingan dan bimbingan. Latihan kader yang dilakukan secara kesinambungan berupa pelatihan dasar dan berjenjang yang berpedoman pada modul pelatihan kader. $^{7}$

Pada kelompok I, cakupan kunjungan posyandu, pada awal kegiatan tahun 90-an tinggi yaitu lebih dari 100 orang pada tiap kegiatan posyandu. Kini, ibu dan anak balita yang berkunjung ke posyandu menurun banyak, rata-rata 15 orang dan tidak lebih dari 20 orang. Namun, pada saat pemberian vitamin $A$, jumlah pengunjung meningkat sampai lebih dari 100 orang. Pada kelompok II, belum semua keluarga membawa balita ke posyandu setiap bulan sehingga target kunjungan ibu hamil ke posyandu belum tercapai.

Untuk meningkatkan kualitas dan penghargaan pada kader, kelompok I memberikan insentif, sedangkan kelompok II menginginkan masukan dari pihak kelurahan (ibu lurah), karena hingga kini belum pernah berkunjung guna memotivasi peningkatan kualitas dan penghargaan pada kader, yang lebih penting adalah memantau langsung kegiatan posyandu. Usaha lain adalah melatih kader agar terampil melayani peserta posyandu.

Ada beberapa cara kader untuk menggerakkan para ibu balita ke posyandu, seperti yang dilakukan oleh kelompok I antara lain: 1) Lokasi Posyandu di blok B yang ditata sedemikian rupa supaya bersih yang berdampingan dengan wartel di depan masjid AlMuhajirin. 2) Melalui undangan dan didatangi rumahrumah ibu balita dan pengumuman lewat masjid. 3) Kader mengutamakan kehadiran para ibu balita membawa anaknya ke posyandu meskipun tidak membawa Kartu Menuju Sehat (KMS). 5) Memberi hadiah bagi ibu yang secara rutin membawa balitanya sejak usia 0-60 bulan. 6) Para petugas kader maupun puskesmas memberi contoh kepada masyarakat untuk membawa balita ke posyandu.

Kelompok II melakukan usaha yang cukup baik, meliputi: 1) Kunjungan rumah ibu balita dan mengajak 
memantau kesehatan balita ke posyandu. 2) Memberi informasi melalui telepon. 3) Pengumuman melalui mesjid terdekat (Masjid Al-Falah). Upaya-upaya tersebut sesuai dengan Pedoman Umum Revitalisasi Posyandu 2001. Kunjungan rumah dilakukan oleh kader dan jika perlu didampingi oleh tenaga kesehatan, tokoh masyarakat atau unsur LSM pada waktu sebelum dan sesudah kegiatan posyandu. Kegiatan tersebut antara lain meliputi: a) Penyampaian undangan kepada kelompok sasaran. b) Pemutakhiran data bayi, balita, ibu hamil, ibu menyusui dan pemetaan keluarga miskin. c) Intensifikasi penyuluhan gizi dan kesehatan dasar. d) Tindak lanjut temuan di posyandu dengan pemberian PMT.

Sejak didirikan kegiatan posyandu di kelompok I terus berlanjut tidak pernah berhenti. Sebaliknya di kelompok II pernah terhenti, sebagai akibat pengurus/ kader berpindah rumah. Kriteria posyandu pada kelompok I adalah Pratama Madya, meskipun pembiayaannya sebagian besar disubsidi warga. Kriteria posyandu kelompok II adalah mandiri, berdasarkan kenyataan bahwa pembiayaan berasal dari warga.

Kriteria posyandu dinyatakan Pratama juga karena kegiatannya yang belum berjalan secara rutin setiap bulan; aktifitas kader terbatas, frekuensi penimbangan kurang dari delapan kali per tahun dan rata-rata jumlah kader kurang dari 5 orang. Kriteria Posyandu Madya meliputi pelaksanaan kegiatan lebih dari delapan kali per tahun, dengan jumlah kader lima orang atau lebih. Cakupan program utama yang meliputi KB, KIA, gizi, imunisasi masih rendah $(<50 \%)$. Kriteria Posyandu Purnama antara lain meliputi: frekuensi lebih dari delapan kali per tahun; rata-rata jumlah kader lima orang atau lebih; cakupan program utamanya (KB, KIA, gizi, imunisasi $(>50 \%)$, sudah melaksanakan program tambahan bahkan Dana Sehat yang sederhana. Sedangkan kriteria Posyandu Mandiri meliputi kegiatan teratur, cakupan program utama baik serta ada program tambahan dan Dana Sehat yang menjangkau lebih dari 50\% kepala keluarga. ${ }^{2}$

\section{Kesimpulan}

Kegiatan posyandu di Pondok Cilegon Indah masih bertahan sampai kini. Kemampuan ibu untuk menerima informasi dari posyandu cukup baik, tetapi kesadaran ibu membawa balita ke posyandu masih kurang. Aktifitas kader menghidupkan kegiatan posyandu cukup baik. Kelayakan fasilitas yang mendukung program posyandu di Perumahan Pondok Cilegon Indah masih sebatas pada layanan minimal posyandu.

\section{Saran}

Perlu meningkatkan kelayakan fasilitas yang mendukung kegiatan posyandu antara lain meliputi alat timbangan yang lebih akurat, tempat anak bermain yang aman dan terarah. Kualitas kegiatan posyandu masih perlu ditingkatkan bukan saja dengan membuat kegiatan baru yang berdampak baik terhadap kesehatan dan status gizi anak, tetapi juga dapat menarik minat ibu balita untuk mengunjungi posyandu.

\section{Daftar Pustaka}

1. Effendy, Nasrul. Dasar-dasar keperawatan kesehatan masyarakat. Edisi 2. Jakarta: EGC; 1999.

2. Departemen Kesehatan RI. Indonesia sehat 2010, visi baru, misi, kebijakan dan strategi pembangunan kesehatan. Jakarta: Depkes RI; 1999.

3. Departemen Kesehatan RI. Informasi ringkas paradigma sehat Indonesia sehat 2010. Jakarta: Depkes RI; 2002.

4. Dinas Kesehatan Propinsi Daerah Tingkat I Jawa Barat. Buku pedoman telaah kemandirian posyandu. Proyek PKM-CHN III. Jakarta: Departemen Kesehatan; 1994.

5. Arikunto, S. Metodologi penelitian kesehatan. Jakarta: PT. Rineka Cipta; 2002.

6. Notoatmojo, S. et.al. Pendidikan dan perilaku kesehatan. Jakarta: PT. Rineka Cipta; 2003.

7. Direktur Jenderal Bina Pemberdayaan Masyarakat. Pedoman umum revitalisasi posyandu. Jakarta: Departemen Dalam Negeri dan Otonomi Daerah Republik Indonesia; 2001.

8. Posyandu: penting untuk kesehatan ibu dan anak. Republika. 19 Juni 2005. 